\title{
CYBER BULLYING PADA ANAK DALAM PERSPEKTIF POLITIK HUKUM PIDANA : KAJIAN TEORETIS TENTANG UNDANG-UNDANG NO. 11 TAHUN 2008 TENTANG INFORMASI DAN TRANSAKSI ELEKTRONIK SEBAGAIMANA DIUBAH DENGAN UNDANG-UNDANG NO. 19 TAHUN 2016
}

\author{
Oleh : \\ Subaidah Ratna Juita, Amri Panahatan Sihotang, Ariyono \\ Fakultas Hukum, Universitas Semarang, e-mail: ratna.juita@usm.ac.id \\ Fakultas Hukum, Universitas Semarang, e-mail: amripanahatan@yahoo.co.id \\ Fakultas Hukum, Universitas Semarang, e-mail: yonoariyono66@gmail.com
}

\begin{abstract}
ABSTRAK
Penelitian ini adalah merupakan pembahasan dan pengkajian secara teoretis normatif mengenai politik hukum pidana dalam penanggulangan tindak pidana pada anak berkaitan dengan pembaruan dalam subsistem substansi dari hukum pidana anak, serta merupakan pembangunan dalam sistem hukum Indonesia yang berorientasi pada perlindungan terhadap anak korban cyber bullying. Permasalahan dalam penelitian ini berkaitan dengan politik hukum pidana dalam terhadap cyber bullying pada Anak. Adapun metode pendekatan yang digunakan dalam penelitian ini adalah pendekatan yuridis normatif yang dilakukan terhadap data sekunder. Data sekunder diperoleh melalui peraturan perundang-undangan, buku-buku, dan jurnal ilmiah. Metode pengumpulan data yang digunakan yaitu melalui studi pustaka. Metode analisis data menggunakan analisis deskriptif yang dikaji berdasarkan obyek kajian hukum pidana pada cyber bullying, kemudian dari obyek penelitian tersebut peneliti menganalisis dengan menggunakan teori politik hukum pidana. Dengan demikian, pendekatan yuridis-normatif dalam penelitian ini digunakan untuk menganalisis permasalahan yang berkaitan dengan perilaku cyber bullying pada Anak dalam perspektif politik hukum pidana. Berdasarkan hasil penelitian, dapat disimpulkan bahwa politik hukum pidana dalam terhadap cyber bullying pada anak dapat ditelusuri berdasarkan Pasal 76 C jo. Pasal 80 (1) UU Perlindungan Anak, yaitu dalam hal tindakan cyber bullying yang dilakukan pada anak, maka terhadap pelaku dapat dikenakan sanksi pidana penjara paling lama 3 (tiga) tahun 6 (enam) bulan dan/atau denda paling banyak Rp72.000.000,00 (tujuh puluh dua juta rupiah).
\end{abstract}

Kata kunci: Politik hukum pidana; Cyber bullying; Anak; 


\begin{abstract}
This research is a form of action taken in the efforts of legal countermeasures carried out in various processes, and also in the Indonesian legal system that focuses on violence against cyber bullying. Problems in this study relate to legal policies in combating cyber bullying in children. While the method used in this study is a normative juridical approach to secondary data. Secondary data in the form of making regulations, books, and scientific journals. Data collection methods that use literature study. Data analysis method uses descriptive analysis that explores the object of cyber bullying, then from the object of the research the researcher uses political theory of criminal law. Thus, the juridical-normative approach in this study is to analyze the behavior that is happening in children in the perspective of criminal law politics. Based on the results of the study, it can be concluded that legal policy in the context of cyber bullying in children can be traced based on Article 76 C jo. Article 80 (1) of the Child Protection Act, namely in the case of cyber bullying actions carried out on children, it can be subject to a prison sentence of a maximum of 3 (three) years 6 (six) months and / or a maximum fine of Rp. 72,000,000.00 (seventy two million rupiah).
\end{abstract}

\title{
Keywords: Criminal law politics; Cyber bullying; Children;
}

\section{PENDAHULUAN}

Perkembangan di bidang informasi, komunikasi dan teknologi melalui media internet pada saat ini adalah sangat cepat dan berdampak pada hampir seluruh aspek kehidupan di dalam masyarakat. Salah satu dampak positif dari perkembangan yang sangat cepat ini adalah terhadap perubahan interaksi masyarakat yang menjadi seperti tanpa batas atau lebih dikenal dengan istilah borderless world. Tetapi, perkembangan ini juga memberikan dampak negatif yang peluang terjadinya kejahatan. Kejahatan yang timbul akibat perkembangan dan pemanfaatan media internet dapat berupa kejahatan jenis baru dan dapat pula berupa kejahatan yang sudah ada sejak lama tetapi bentuknya meluas. Cyber bullying adalah kejahatan yang merupakan bentuk perluasan dari bullying yang selama ini terjadi secara konvensional. ${ }^{1}$

Cyber bullying adalah salah satu fenomena yang terjadi akibat pengaruh negatif dari perkembangan teknologi. Cyber bullying adalah kejahatan yang merupakan bentuk perluasan dari bullying yang selama ini terjadi secara konvensional. Cyber bullying berbentuk kejahatan secara verbal di dalam cyber space dan mayoritas memakan korban anak-anak. ${ }^{2}$ Kebutuhan komunikasi di dunia maya digunakan oleh anak-anak untuk menjalin hubungan sosial dengan teman-teman yang ada di sekitar mereka maupun

\footnotetext{
${ }^{1}$ Novan Andy Wiyana, Save Our Children From School Bullying, (Yogyakarta: AR-RUZZ Media, 2012), halaman 18

${ }^{2}$ Ibid.
} 
teman baru yang belum dikenal sebelumnya. Tujuan untuk menjalin hubungan di dunia maya tersebut juga beranekaragam, mulai dari untuk mencari informasi, menjalin hubungan dengan teman dekat, mencari teman baru, dan alasan lainnya, untuk melakukan hubungan sosial yang ada di dunia maya tersebut anak-anak memanfaatkan media sosial seperti facebook, twitter, instagram, dan media sosial lainnya yang dapat menyediakan fasilitas untuk memenuhi keinginan dan hasrat untuk berkomunikasi. Orang dewasa dan anak-anak yang menggunakan teknologi dan internet untuk tujuan sarana komunikasi, hal inilah yang menyebabkan awal mula terjadinya cyber bullying.

Di saat melakukan komunikasi dengan memanfaatkan media sosial tersebut, anak dapat menjadi korban intimidasi berupa penghinaan, pencemaran nama baik, pemerasan dan maupun tindak intimidasi lainnya yang dikirim melalui pesan teks, gambar maupun video. Namun cyber bullying sendiri hanya dapat terjadi dengan anak-anak, karena cyber bullying dianggap valid bila pelaku dan korban berusia dibawah 18 tahun dan secara hukum belum dianggap dewasa. Bila salah satu pihak yang terlibat (atau keduanya) sudah berusia di atas 18 tahun, maka kasus yang terjadi akan dikategorikan sebagai cyber stalking atau sering juga disebut cyber harassment. ${ }^{3}$

Cyber bullying merupakan aktivitas menggunakan teknologi informasi dan komunikasi secara disengaja, berulang-ulang dan terus-menerus mengandung permusuhan yang dilakukan oleh individu atau kelompok dengan tujuan untuk melukai perasaan orang lain (kelompok atau indvidu). Cyber bullying dapat dikategorikan sebagai bullying secara verbal karena pelaku melakukan tindakan bullying secara tidak langsung seperti mengejek, menghina, mengolok-olok, mencela, menyebarkan rumor, bahkan mengancam dengan menggunakan media elektronik. Cyber bullying yang berkepanjangan bisa mematikan rasa kepercayaan diri seseorang terutama pada anak atau remaja, membuat seseorang menjadi murung, depresi, selalu merasa bersalah atau gagal karena tidak mampu mengatasi sendiri gangguan yang menimpanya. Bahkan ada pula korban cyber bullying yang berpikir untuk mengakhiri hidupnya karena tak tahan lagi diganggu.

Pemerintah perlu memberikan perlindungan bagi anak korban cyber bullying dengan mengesahkan peraturan perundang-undangan yang ditujukan untuk melindungi kepentingan anak sebagai korban cyber bullying. Hal ini kemudian direspon secara positif oleh pemerintah yang pada bulan Maret 2008 telah mensahkan Undang-Undang

\footnotetext{
${ }^{3}$ https://id.wikipedia.org./wiki/Intimidasi duni maya (diakses pada tanggal 1 Februari 2018).
} 
Nomor 11 Tahun 2008 tentang Informasi dan Transaksi Elektronik.

Seiring perkembangan penggunaan media sosial, dan bahwa untuk menjamin pengakuan serta penghormatan atas hak dan kebebasan orang lain dan untuk memenuhi tuntutan yang adil sesuai dengan pertimbangan keamanan dan ketertiban umum dalam suatu masyarakat yang demokratis termasuk dalam memberikan perlindungan bagi anak korban perilaku cyber bullying dan sekaligus mengakomodasi pengaturan mengenai dunia maya dan segala hal yang berkaitan dengannya, perlu dilakukan perubahan terhadap Undang-Undang Nomor 11 Tahun 2008 tentang Informasi dan Transaksi Elektronik agar terwujud keadilan, ketertiban umum, dan kepastian hukum, maka diundangkanlah Undang-Undang Nomor 19 Tahun 2016 tentang Perubahan atas Undang-Undang Nomor 11 Tahun 2008 tentang Informasi dan Transaksi Elektronik yang selanjutnya disebut UU ITE. Filosofi mengenai disahkannya undang-undang ini didasarkan pada pemikiran yang terdapat di dalam konsideran yang menyatakan:

Bahwa globalisasi informasi telah menempatkan Indonesia sebagai bagian dari masyarakat informasi dunia sehingga mengharuskan dibentuknya pengaturan mengenai pengelolaan Informasi dan Transaksi Elektronik di tingkat nasional sehingga pembangunan Teknologi Informasi dapat dilakukan secara optimal, merata dan menyebar ke seluruh lapisan masyarakat guna mencerdaskan kehidupan bangsa. ${ }^{4}$

\section{KAJIAN PUSTAKA}

\section{a. Tinjauan tentang Cyber Bullying}

Bullying merupakan suatu bentuk perilaku agresif yang diwujudkan dengan perlakuan secara tidak sopan dan penggunaan kekerasan atau paksaan untuk mempengaruhi orang lain, yang dilakukan secara berulang atau berpotensi untuk terulang, dan melibatkan ketidakseimbangan kekuatan dan/atau kekuasaan. Perilaku ini dapat mencakup pelecehan verbal, kekerasan fisik atau pemaksaan, dan dapat diarahkan berulangkali terhadap korban tertentu, mungkin atas dasar ras, agama, gender, seksualitas, atau kemampuan.

Salah satu bagian dari Cyber crime yang menjadi permasalahan dewasa ini yaitu kekerasan melalui media elektronik atau perilaku bullying melalui media maya yang biasa disebut Cyber bullying. Cyber bullying merupakan salah satu bentuk atau dimensi baru dari kejahatan masa kini yang mendapat perhatian luas di dunia internasional.

4 Bagian menimbang Undang-Undang Nomor 11 Tahun 2008 tentang Informasi dan Transaksi Elektronik. 
Perilaku jahat ini berawal dari perkembangan teknologi informasi dan komunikasi yang pesat namun tidak diikuti dengan pemahaman pemanfaatan teknologi yang baik dan benar. Selain itu perilaku jahat ini juga disebabkan karena kurangnya kesadaran etika disaat menggunakan teknologi informasi dan komunikasi oleh penggunanya. Penggunaan kata cyber dalam cyberspace, cybercrime, dan cyberlaw, serta istilah lain yang menggunakan kata cyber berkembang dari penggunaan terminologi cybernetic oleh Nobert Wiener di tahun 1984 dalam bukunya yang berjudul Cybernetics or Control and Communication in the Animal and the Machine. ${ }^{5}$

Pengertian cyber bullying di atas menjelaskan bahwa cyber bullying adalah penggunaan yang disengaja dan berulang kali dengan menggunakan telepon seluler, komputer, dan perangkat komunikasi elektronik lainnya untuk melecehkan dan mengancam orang lain. Secara umum cyber bullying yaitu perlakuan kasar yang dilakukan oleh seseorang atau sekelompok orang, menggunakan bantuan alat elektronik yang dilakukan berulang dan terus menerus pada seorang target yang kesulitan membela diri.

Cyber bullying adalah tindakan yang menggunakan teknologi informasi dan komunikasi untuk keperluan yang disengaja, dilakukan terus menerus, dengan tujuan untuk merugikan orang lain dengan cara mengintimidasi, mengancam, menyakiti/menghina harga diri orang lain, hingga menimbulkan perrmusuhan oleh seorang individu atau kelompok penggunaan teknologi komunikasi dalam penggunaan layanan internet dan teknologi mobile seperti halaman web dan grup diskusi serta telepon selular dan pesan teks (SMS).

\section{b. Anak sebagai Korban Cyber Bullying}

Pengertian anak dapat dilihat dalam beberapa ketentuan perundang-undangan, namun seringkali pengertian anak menjadi berbeda tergantung pada sudut pandang pembentukan undang-undang tersebut. Berdasarkan ketentuan yang terdapat dalam Pasal 1 angka 2 UU No. 11 Tahun 2012 tentang Sistem Peradilan Pidana Anak (SPPA), merumuskan bahwa: "Anak yang Berhadapan dengan Hukum adalah anak yang berkonflik dengan hukum, anak yang menjadi korban tindak pidana, dan anak yang menjadi saksi tindak pidana”. Anak yang berhadapan dengan hukum dapat juga dikatakan sebagai anak yang terpaksa berkontak dengan sistem pengadilan pidana

\footnotetext{
5 Josua Sitompul, Cyberspace, Cybercrime, Cyberlaw: Tinjauan Aspek Hukum Pidana, (Jakarta: Tatanusa, 2012), halaman 3-4.
} 
karena:

1) Disangka, didakwa, atau dinyatakan terbukti bersalah melanggar hukum; atau

2) Telah menjadi korban akibat perbuatan pelanggaran hukum yang dilakukan orang/kelompok orang/lembaga/negara terhadapnya; atau

3) Telah melihat, mendengar, merasakan, atau mengetahui suatu peristiwa pelanggaran hukum. ${ }^{6}$

Dilihat ruang lingkupnya maka anak yang berhadapan dengan hukum dapat dibagi menjadi :

1) Pelaku atau tersangka tindak pidana;

2) Korban tindak pidana;

3) Saksi suatu tindak pidana.

Lebih lanjut mengenai anak yang berhadapan dengan hukum yang dikualifikasikan sebagai anak korban tindak pidana secara tegas dirumuskan dalam Pasal 1 angka 4 UU No. 11 Tahun 2012 tentang Sistem Peradilan Pidana Anak (SPPA) sebagai anak yang belum berumur 18 (delapan belas) tahun yang mengalami penderitaan fisik, mental, dan/atau kerugian ekonomi yang disebabkan oleh tindak pidana.

\section{METODE PENELITIAN}

\section{a. Metode Pendekatan}

Metode pendekatan yang akan digunakan dalam penelitian ini adalah pendekatan yuridis normatif, yaitu dengan mengkaji atau menganalisis data sekunder yang berupa bahan hukum primer, dengan memahami hukum sebagai perangkat peraturan atau norma- norma positif di dalam sistem perundang-undangan yang mengatur mengenai perilaku cyber bullying pada Anak, sekaligus juga menggunakan bahan hukum sekunder, dan tersier. Jadi pembahasan dalam penelitian ini dipahami sebagai kajian kepustakaan terhadap data sekunder. Dengan demikian, pendekatan yuridis-normatif dalam kajian ini digunakan untuk menganalisis permasalahan yang berkaitan dengan perilaku cyber bullying pada Anak, dan pada tataran aplikatif penelitian ini akan menganalisa grand design politik hukum pidana dalam penanggulangan perilaku cyber bullying pada Anak.

\section{b. Metode Pengumpulan dan Analisis Data}

\footnotetext{
${ }^{6}$ Apong Herlina, Perlindungan terhadap Anak yang Berhadapan dengan Hukum, Buku Saku untuk Polisi, (Jakarta: Unicef, 2004), hal 17.
} 
Metode pengumpulan data dilakukan melalui studi literatur. Data yang dikumpulkan adalah data sekunder. Data hasil penelitian yang berupa data sekunder akan dianalisis secara kualitatif kemudian diidentifikasi serta dilakukan kategorisasi. Dari hasil analisis tersebut kemudian akan ditarik kesimpulan sebagai jawaban atas permasalahan yang ada.

\section{HASIL DAN PEMBAHASAN}

Cyber bullying merupakan salah satu dimensi baru dari kejahatan masa kini yang mendapat perhatian luas di dunia internasional. Kejahatan ini berawal dari perkembangan teknologi informasi dan komunikasi yang pesat namun tidak diikuti dengan pemahaman pemanfaatan teknologi yang baik dan benar. Selain itu kejahatan ini juga disebabkan karena kurangnya kesadaran etika disaat menggunakan teknologi informasi dan komunikasi oleh penggunanya.

Kebijakan penanggulangan cyber bullying dengan hukum pidana termasuk bidang penal policy yang merupakan bagian dari criminal policy (kebijakan penanggulangan kejahatan). Menurut Barda Nawawi Arief, dilihat dari sudut criminal policy, upaya penanggulangan cyber bullying tidak dapat dilakukan semata-mata secara parsial dengan hukum pidana (sarana penal), tetapi harus ditempuh pula dengan pendekatan integral/sistematik. Sebagai salah satu bentuk high tech crime yang dapat melampaui batas-batas negara (bersifat transnational/transborder), merupakan hal yang wajar jika upaya penanggulangan cyber bullying juga harus ditempuh dengan pendekatan teknologi (techno prevention). ${ }^{7}$ Di samping itu, diperlukan pula pendekatan budaya/kultural, pendekatan moral/edukatif, dan bahkan pendekatan global (kerja sama internasional). ${ }^{8}$ Kebijakan kriminalisasi merupakan suatu kebijakan dalam menetapkan suatu perbuatan yang semula bukan tindak pidana (tidak dipidana) menjadi suatu tindak pidana (perbuatan yang dapat dipidana). Kebijakan / politik hukum pidana yang ditekankan pada penanggulangan kejahatan/penegakan hukum pidana/politik hukum pidana mengenai masalah cyber bullying pada anak dalam penelitian ini adalah terbatas pada aspek/tahap kebijakan formulasi dari segi materil, yaitu bagaimana formulasi perumusan suatu delik serta sanksi apa yang akan dikenakan terhadap pelanggarnya.

\footnotetext{
${ }^{7}$ Barda Nawawi Arief, Tindak Pidana Mayantara, Perkembangan Kajian Cyber Crime di Indoneia, (Jakarta: PT. Raja Grafindo, 2002), halaman 90.

8 Barda Nawawi Arief, Sari Kuliah Perbandingan Hukum Pidana, (Jakarta: PT Raja Grafindo, 2002), halaman 253-256.
} 
Berikut ini adalah analisa teoretis tentang Undang-Undang No. 11 Tahun 2008 tentang Informasi dan Transaksi Elektronik sebagaimana diubah dengan Undang-Undang No. 19 Tahun 2016 (UU ITE) berkaitan dengan cyber bullying pada anak dalam perspektif politik hukum pidana :

Kitab Undang-Undang Hukum Pidana Indonesia (KUHP) merupakan sistem induk bagi peraturan-peraturan hukum pidana di Indonesia. Perumusan tindak pidana di dalam KUHP kebanyakan masih bersifat konvensional dan belum secara langsung dikaitkan dengan perkembangan cyber bullying yang merupakan bagian dari cyber crime. Di samping itu, mengandung berbagai kelemahan dan keterbatasan dalam menghadapi perkembangan teknologi dan high tech crime yang sangat bervariasi.

Perilaku cyber bullying jika diinterpretasikan di dalam KUHP masuk ke dalam pasal penghinaan, fitnah, pengancaman dan tindakan kesusilaan. Namun pasal-pasal tersebut mengalami kekurangan untuk diterapkan untuk ranah dunia maya, hal ini disebabkan karena KUHP yang dibuat jauh sebelum perkembangan dunia maya. Kekurangannya ada di kata "diketahui umum" dan "di muka umum". Menurut Putusan Mahkamah Konstitusi No. 50/PUU-VI/2008 menyatakan, penghinaan yang diatur dalam KUHP tidak menjangkau penghinaan dan pencemaran nama baik yang dilakukan di dunia cyber karena ada unsur "di muka umum". Memasukkan pengertian "diketahui umum", "di muka umum", dan "disiarkan" tetap tidak mencukupi. Diperlukan sebuah rumusan yang bersifat ekstensif, yaitu "mendistribusikan" dan/atau "mentransmisikan" dan/atau "membuat dapat diakses". KUHP jika dilihat dari pengaturan tentang penghinaan sebenarnya mengatur penghinaan di kehidupan nyata, sedangkan penghinaan yang terkait dengan tindakan cyber bullying sendiri dilakukan dalam dunia maya (cyber space). KUHP juga tidak memberikan penjelasan secara rinci tentang yang dimaksud dengan penghinaan, sehingga ini dapat menjadi kelemahan.

Berkaitan dengan permasalah tersebut, berdasarkan keputusan Mahkamah Konstitusi Nomor 50/PUU-VI/2008 telah memberikan uraian jelas bahwa KUHP memiliki kekurangan terkait dengan beberapa unsur-unsur tindak pidana jika ingin dikaitkan dengan kejahatan yang ada di dunia maya. sehingga seharusnya untuk menanggulangi kejahatan berkaitan dengan rana dunia maya, seperti tindakan cyber bullying harus di buat undang- undang khusus terkait dengan kejahatan komputer sehingga dapat mencakup kejahatan yang ada di dalam dunia maya. 
Dalam perkembangannya, saat ini telah ada perundang-undangan di luar KUHP yang berkaitan dengan kejahatan di bidang teknologi informasi dan komunikasi yaitu Undang-Undang Nomor 11 Tahun 2008 tentang Informasi dan Transaksi Elektronik sebagaimana diubah dengan Undang-Undang No. 19 Tahun 2016, yang selanjutnya disebut UU ITE. Undang-Undang ini bertujuan untuk mengharmonisasikan antara instrument peraturan hukum nasional dengan instrument-instrument hukum internasional yang mengatur teknologi informasi diantaranya, yaitu : The United Nations Commissions on International Trade Law (UNCITRAL), World Trade Organization (WTO), Uni Eropa (EU), APEC, ASEAN, dan OECD. Masing-masing organisasi mengeluarkan peraturan yang mengisi satu sama lain. Dan juga instrument hukum internasional ini telah diikuti oleh beberapa negara seperti: Australia (The cyber crime act 2001), Malaysia (Computer Crime Act 1997), Amerika Serikat (Federal legislation: update April 2002 UNITED STATE CODE), Kongres PBB ke 8 di Havana, Kongres ke X di Wina, kongres XI 2005 di Bangkok, berbicara tentang The Prevention of Crime and the Treatment of Offender. Dalam Kongres PBB X tersebut dinyatakan bahwa negara-negara anggota harus berusaha melakukan harmonisasi ketentuan-ketentuan yang berhubungan dengan kriminalisasi, pembuktian dan prosedur (States should seek harmonization of relevan provision on criminalization, evidence, and procedure $)^{9}$ dan negara-negara Uni Eropa yang telah secara serius mengintegrasikan regulasi yang terkait dengan hukum positif (existing law) nasionalnya. ${ }^{10}$

UU ITE merupakan undang-undang yang mengatur tentang kejahatan-kejahatan yang berbasis teknologi (cyber crime), sedangkan tindakan cyber bullying merupakan bagian/jenis dari cyber crime, berikut identifikasi peneliti :

\section{a. Sistem perumusan tindak pidana dalam UU ITE}

Ketentuan pidana dalam UU ITE terdapat dalam Bab XI Pasal 45 sampai dengan Pasal 52. Berikut perumusan beberapa pasal dalam Bab XI mengenai ketentuan pidana :

\section{Pasal 45 UU ITE :}

(1) Setiap Orang yang memenuhi unsur sebagaimana dimaksud dalam Pasal 27 ayat (1), ayat (2), ayat (3), atau ayat (4) dipidana dengan pidana penjara paling lama 6 (enam) tahun dan/atau denda paling banyak Rp 1.000.000.000,00 (satu miliar rupiah).

\footnotetext{
${ }^{9}$ Barda Nawawi Arif, Tindak Pidana Mayantara, Perkembangan Kajian Cyber Crime di Indonesia, (Jakarta: PT. Raja Grafindo, 2002), halaman 5.

${ }^{10} \mathrm{http} / / / g o o g l e . c o . i d / N a s k a h$ Akademik Rancangan Undang-Undang tentang informasi dan transaksi elektronik .
} 
(2) Setiap Orang yang memenuhi unsur sebagaimana dimaksud dalam Pasal 28 ayat (1) atau ayat (2) dipidana dengan pidana penjara paling lama 6 (enam) tahun dan/atau denda paling banyak Rp 1.000.000.000,00 (satu miliar rupiah).

(3) Setiap Orang yang memenuhi unsur sebagaimana dimaksud dalam Pasal 29 dipidana dengan pidana penjara paling lama 12 (dua belas) tahun dan/atau denda paling banyak Rp 2.000.000.000,00 (dua miliar rupiah).

\section{Pasal 52 UU ITE :}

(1) Dalam hal tindak pidana sebagaimana dimaksud dalam Pasal 27 ayat (1) menyangkut kesusilaan atau eksploitasi seksual terhadap anak dikenakan pemberatan sepertiga dari pidana pokok.

(2) Dalam hal perbuatan sebagaimana dimaksud dalam Pasal 30 sampai dengan Pasal 37 ditujukan terhadap Komputer dan/atau Sistem Elektronik serta informasi Elektronik dan/atau Dokumen Elektronik milik Pemerintah dan/atau yang digunakan untuk layanan publik dipidana dengan pidana pokok ditambah sepertiga.

(3) Dalam hal perbuatan sebagaimana dimaksud dalam Pasal 30 sampai dengan Pasal 37 ditujukan terhadap Komputer dan/atau Sistem Elektronik serta informasi Elektronik dan/atau Dokumen Elektronik milik Pemerintah dan/atau badan strategis termasuk dan tidak terbatas pada lembaga pertahanan,bank sentral, perbankan, keuangan, lembaga internasional, otoritas penerbangan diancam dengan pidana maksimal ancaman pidana pokok masing-masing Pasal ditambah dua pertiga.

(4) Dalam hal tindak pidana sebagaimana dimaksud dalam Pasal 27 sampai dengan Pasal 37 dilakukan oleh korporasi dipidana dengan pidana pokok ditambah dua pertiga.

Kualifikasi delik yang diatur dalam Undang-Undang ITE tersebut diatur dalam Pasal 52 yang dikualifikasikan sebagai kejahatan.

Berdasarkan ketentuan pasal-pasal dalam Bab XI mengenai ketentuan pidana dalam UU ITE, maka dapat diidentifikasikan beberapa perbuatan yang dilarang (unsur tindak pidana) yang erat kaitannya dengan tindakan cyber bullying pada tiap-tiap pasalnya sebagai berikut :

Pasal 27 ayat (3) dengan unsur tindak pidana: mendistribusikan dan/atau mentransmisikan dan/atau membuat dapat diaksesnya informasi Elektronik dan/atau Dokumen Elektronik yang memiliki muatan penghinaan dan/atau pencemaran nama baik. (Terkait dengan aksi cyber bullying yang berbentuk cyber harrasment).

Pasal 27 ayat (4) dengan unsur tindak pidana: mendistribusikan dan/atau mentransmisikan dan/atau membuat dapat diaksesnya informasi Elektronik dan/atau Dokumen Elektronik yang memiliki muatan pemerasan dan/atau pengancaman. (Terkait dengan aksi cyber bullying yang berbentuk cyber stalking).

Pasal 28 ayat (2) dengan unsur tindak pidana: menyebarkan informasi yang ditujukan untuk menimbulkan rasa kebencian atau permusuhan individu dan/atau 
kelompok masyarakat tertentu berdasarkan atas suku, agama, ras, dan antargolongan (SARA). ( Terkait dengan aksi cyber bullying yang berbentuk cyber harrasment).

Pasal 29 dengan unsur tindak pidana: mengirimkan informasi Elektronik dan/atau Dokumen Elektronik yang berisi ancaman kekerasan atau menakut-nakuti yang ditujukan secara pribadi. (Terkait dengan aksi cyber bullying yang berbentuk cyber stalking).

Pasal 30 ayat (1) dengan unsur tindak pidana: mengakses Komputer dan/atau Sistem Elektronik milik Orang lain dengan cara apa pun. (Terkait dengan aksi cyber bullying yang berbentuk impersonation).

Pasal 32 ayat (2) dengan unsur tindak pidana: memindahkan atau mentransfer Informasi Elektronik dan/atau Dokumen Elektronik kepada sistem Elektronik Orang lain yang tidak berhak. (Terkait dengan aksi cyber bullying yang berbentuk outing and trickery) .

Mengenai unsur sifat 'melawan hukum', dalam undang-undang ITE tersebut disebutkan secara tegas, unsur 'sifat melawan hukum tersebut dapat dilihat pada perumusan “... setiap orang dengan sengaja dan tanpa hak atau melawan hukum sebagaimana dalam pasal.." seperti dirumuskan dalam Pasal 27 sampai dengan Pasal 32 tersebut di atas, sehingga dapat disimpulkan bahwa dengan disebutkannya secara tegas unsur 'sifat melawan hukum' terlihat ada kesamaan ide dasar antara UU ITE dengan KUHP yang masih menyebutkan unsur sifat melawan hukumnya suatu perbuatan. Berbeda dengan Konsep KUHP baru yang sekarang tengah disusun yang menentukan bahwa meskipun unsur 'sifat melawan hukum' tidak dicantumkan secara tegas, tetapi suatu delik harus tetap dianggap bertentangan dengan hukum.

Melihat berbagai ketentuan yang telah dikriminalisasikan dalam Undang-Undang ITE tersebut, nampak adanya kriminalisasi terhadap perbuatan-perbuatan yang berhubungan dengan penyalahgunaan penggunaan di bidang teknologi informasi dan Transaksi Elektronik, yang berbentuk tindakan cyber bullying. Oleh karena itu, nampak bahwa perspektif Undang-Undang Informasi dan Transaksi Elektronik adalah menekankan pada aspek penggunaan/keamanan Sistem Informasi Elektronik atau Dokumen Elektronik, dan penyalahgunaan di bidang teknologi dan transaksi elektronik yang dilakukan oleh para pelaku cyber bullying.

\section{b. Sistem Perumusan Pertanggungjawaban pidana dalam Undang-Undang ITE}


Dalam hukum pidana dikenal asas yang paling fundamental, yakni Asas "Tiada Pidana Tanpa Kesalahan" yang dikenal dengan " keine strafe ohne schuld" atau "geen straf zonder schuld" atau "nulla poena sine culpa". Dari asas tersebut dapat dipahami bahwa kesalahan menjadi salah satu unsur pertanggungjawaban pidana dari suatu subjek hukum pidana. Artinya, seseorang yang diakui sebagai subjek hukum harus mempunyai kesalahan untuk dapat dipidana.Kesalahan adalah dasar untuk pertanggungjawaban. Kesalahan merupakan keadaan jiwa dari sipembuat dan hubungan batin antara si pembuat dan perbuatannya. Mengena keadaan jiwa dari seseorang yang melakukan perbuatan, lazim disebut sebagai kemampuan bertanggung jawab, sedangkan hubungan batin antara si pembuat dan perbuatannya itu merupakan kesengajaan, kealpaan, serta alasan pemaaf. ${ }^{11}$

Dengan demikian, untuk menentukan adanya kesalahan, dalam pidana subjek hukum harus memenuhi beberapa unsur, antara lain : 1) Adanya kemampuan bertanggung jawab pada si pelaku, 2) perbuatannya tersebut berupa kesengajaan (dolus) atau kealpaan (culpa), 3) Tidak adanya alasan penghapus kesalahan atau tidak adanya alasan pemaaf. Ketiga unsur ini merupakan satu kesatuan yang tidak dapat dipisahkan antara satu dengan yang lain, dimana unsur yang satu bergantung pada unsur yang lain. ${ }^{12}$

Dalam perkembangan hukum pidana kedudukan korporasi sebagai pembuat tindak pidana dan dapat dipertanggungjawabkan terdiri dari beberapa bentuk yaitu: ${ }^{13}$

1. Pengurus korporasi sebagai pembuat dan pengurus yang bertanggung jawab secara pidana;

2. Korporasi sebagai pembuat tindak pidana dan pengurus korporasi yang bertanggung jawab secara pidana;

3. Korporasi sebagai pembuat tindak pidana dan juga sebagai yang bertanggung jawab secara pidana;

4. Pengurus korporasi sebagai pembuat tindak pidana dan pengurus dan korporasi lah yang bertanggung jawab secara pidana.

Melihat perumusan ketentuan pidana dalam Undang-Undang ITE sebagai mana diatur dalam Pasal 45 sampai dengan Pasal 52 maka dapat diidentifikasikan bahwa pelaku tindak pidana atau yang dapat dimintakan pertanggungjawaban pidana dalam undangundang ITE adalah meliputi individu/orang per orang dan korporasi. Ini terbukti dari ketentuan pasal-pasal tersebut yang diawali dengan kata "Setiap orang" dan " korporasi”.

\footnotetext{
${ }^{11}$ Sudarto, Hukum dan Perkembangan Masyarakat, (Bandung: Sinar Baru,1983), hal. 22.

${ }^{12}$ Ibid., halaman 24.

${ }^{13}$ Mohammad Topan, Tindak Pidana Korporasi di Bidang Lingkungan hidup: Perspektif Viktimologi Dalam Pembaharuan Hukum Pidana di Indonesia, (Bandung: Nusa Media, 2009), halaman 45.
} 
Masalah pertanggungjawaban pidana berkaitan erat dengan pelaku tindak pidana. Pelaku yang dapat dipidana adalah orang dan korporasi, yang dijelaskan dalam Pasal 1 sub 21 dan dalam ketentuan pidana UU ITE tersebut. UU ITE mengatur secara lanjut dan terperinci tentang ketentuan pertanggungjawaban pidana terhadap korporasi, karena UU ITE tersebut membedakan pertanggungjawaban pidana terhadap individu dan korporasi, sebagaimana yang tercantum dalam Pasal 52 UU ITE.

\section{c. Sistem Perumusan Sanksi Pidana, Jenis-Jenis Sanksi dan Lamanya Menjalankan Sanksi Pidana dalam UU ITE}

Sistem perumusan sanksi pidana dalam Undang-undang ITE adalah alternatif kumulatif. Hal ini bisa dilihat dalam perumusannya yang menggunakan kata “.. dan/atau. Jenis-jenis sanksi (strafsoort) pidana dalam Undang-undang ITE ini ada dua jenis yaitu pidana penjara dan denda. Sistem Perumusan lamanya pidana (strafmaat) dalam Undangundang ITE ini adalah :

Maximum khusus, pidana penjara dalam UU ITE paling lama 12 tahun/

Maximum khusus pidana dendanya, paling sedikit sebanyak Rp 300.000.000,00 (tiga ratus juta rupiah), dan paling banyak Rp 12.000.000.000,00 (dua belas milyar rupiah).

Berdasarkan pembahasan di atas maka dapat diketahui bahwa dlihat dari perspektif politik hukum pidana, Undang-Undang ITE dapat digunakan untuk menanggulangi jenis perilaku cyber bullying, sebagai suatu fenomena/bentuk baru cyber crime secara umum. Undang-undang ini menekankan pada pengaturan keamanan penggunaan Sistem Informasi Elektronik atau Dokumen Elektronik, dan mengara pada menyalahgunakan Informasi Elektronik untuk tujuan perbuatan-perbuatan tindakan cyber bullying.

Berdasarkan perumusan dan pengaturan mengenai cyber bullying dalam UndangUndang No. 11 Tahun 2008 tentang Informasi dan Transaksi Elektronik sebagaimana diubah dengan Undang-Undang No. 19 Tahun 2016 sebagaimana diuraikan di atas, maka dalam rangka memberikan jaminan perlindungan hukum bagi anak sebagai korban cyber bullying dalam perspektif politik hukum pidana, maka berikut ini adalah analisa yang dilakukan oleh peneliti berkaitan dengan grand design politik hukum pidana dalam penanggulangan cyber bullying pada anak.

Perlindungan terhadap anak merupakan pondasi anak untuk menjadi dewasa menjawab tantangan masa mendatang. Anak sebagai mahluk sosial memiliki kebutuhan berinteraksi dengan lingkungan sekitarnya, bagaimana ia menyesuaikan diri dengan 
orang-orang, baik yang berada di sekolah, rumah atau tempat-tempat pendidikan lainnya. Untuk dapat berkembang anak melakukan berbagai cara agar memahami dunia, melalui dunia pendidikan. Perlindungan terhadap hidup dan penghidupan anak ini masih menjadi tanggung jawab berbagai pihak yaitu kedua orang tuanya, keluarganya, masyarakat, dan juga negara. Perlindungan ini dapat berupa sandang, pangan, dan papan. Tidak hanya itu, perlindungan yang diberikan terhadap seorang anak juga dapat berupa perlindungan terhadap kondisi psikologis atau mental dari anak yaitu terutama perkembangan kejiwaannya. Artinya bahwa anak tersebut dapat berkembang dan hidup secara normal tidak hanya perkembangan fisiknya saja tetapi juga perkembangan jiwa atau psikisnya. Selanjutnya, perlindungan terhadap bentuk perlindungannya ialah perlindungan hukum terhadap korban tindak pidana, dapat diartikan sebagai perlindungan untuk memperoleh jaminan hukum atas penderitaan atau kerugian pihak yang telah menjadi korban tindak pidana.

Keberadaan Undang-Undang Nomor 23 Tahun 2002 tentang Perlindungan Anak sebagaimana telah diubah dengan Undang-Undang Nomor 35 Tahun 2014 tentang Perubahan Undang-Undang Nomor 23 Tahun 2002 tentang Perlindungan Anak yang selanjutnya disebut UU Perlindungan Anak merupakan alat hukum yang mampu melindungi anak dalam berbagai tindak pidana termasuk melindungi anak dari perilaku cyber bullying. Undang-undang ini mengamanatkan bahwa cyber bullying terhadap anak merupakan tindak pidana sehingga pelaku dapat diajukan ke kepolisian atas pendampingan pihak terkait. Secara khusus perlindungan anak sebagai korban cyber bullying telah diatur dalam undang-undng Perlindungan Anak, hal sebagaimana dirumuskan dalam Pasal 76 C jo. Pasal 80 (1) UU Perlindungan Anak. Adapun perumusan dari pasal-pasal tersebut sebagai berikut:

Pasal 76 C :

Setiap orang dilarang menempatkan membiarkan, melakukan, menyuruh melakukan, atau turut serta melakukan kekerasan terhadap Anak.

Pasal 80 (1) :

Setiap Orang yang melanggar ketentuan sebagaimana dimaksud dalam Pasal 76 C, dipidana dengan pidana penjara paling lama 3 (tiga) tahun 6 (enam) bulan dan/atau denda paling banyak Rp72.000.000,00 (tujuh puluh dua juta rupiah).

Dengan demikian, grand design politik hukum pidana dalam penanggulangan cyber bullying pada anak dapat ditelusuri berdasarkan Pasal 76 C jo. Pasal 80 (1) UU Perlindungan Anak, yaitu dalam hal tindakan cyber bullying yang dilakukan pada anak, 
maka terhadap pelaku dapat dikenakan sanksi pidana penjara paling lama 3 (tiga) tahun 6 (enam) bulan dan/atau denda paling banyak Rp72.000.000,00 (tujuh puluh dua juta rupiah).

\section{PENUTUP}

\section{a. Simpulan}

Perilaku cyber bullying pada anak dalam perspektif politik hokum pidana dapat ditelusuri berdasarkan Pasal 76 C jo. Pasal 80 (1) UU Perlindungan Anak, yaitu dalam hal tindakan cyber bullying yang dilakukan pada anak, maka terhadap pelaku dapat dikenakan sanksi pidana penjara paling lama 3 (tiga) tahun 6 (enam) bulan dan/atau denda paling banyak Rp72.000.000,00 (tujuh puluh dua juta rupiah).

\section{b. Saran}

Dilihat dari kurangnya payung hukum bagi korban cyber bullying, khususnya anak sebagai korban di Indonesia, Pasal 27 ayat (3) UU ITE masih dapat dijadikan acuan bagi mereka yang merasa menjadi korban cyber bullying. Oleh karena itu, dari Putusan MK Nomor 50/PUU-VI/2008, diharapkan masyarakat maupun jurnalis yang melakukan aktivitas di dunia cyber dapat mengadukan cyber bullying yang dilakukan terhadap anak berdasarkan pada Pasal 27 ayat (3) UU ITE, dan bukan Pasal 310 dan 311 KUHP.

\section{DAFTAR PUSTAKA}

\section{a. Buku-buku:}

Arief, Barda Nawawi. Bunga Rampai Kebijakan Hukum Pidana. Bandung: Citra Aditya Bakti, 2002.

---------, Tindak Pidana Mayantara, Perkembangan Kajian Cyber Crime di Indoneia. Jakarta: PT. Raja Grafindo, 2002.

----------. Sari Kuliah Perbandingan Hukum Pidana. Jakarta: PT Raja Grafindo, 2002.

Ardy Wiyani, Novan. Save Our Children From School Bullying. Yogyakarta: AR-RUZZ Media, 2012.

Herlina, Apong. Perlindungan terhadap Anak yang Berhadapan dengan Hukum. Buku Saku untuk Polisi. Jakarta: Unicef, 2004.

Sitompul, Josua. Cyberspace, Cybercrime, Cyberlaw: Tinjauan Aspek Hukum Pidana. Jakarta: Tatanusa, 2012. 
Sudarto. Hukum dan Perkembangan Masyarakat. Bandung: Alumni, 1983.

Topan, Mohammad. Tindak Pidana Korporasi di Bidang Lingkungan hidup: Perspektif Viktimologi Dalam Pembaharuan Hukum Pidana di Indonesia. Bandung: Nusa Media, 2009.

\section{b. Peraturan Perundang-undangan:}

Sekretariat Negara RI. Undang-Undang No. 1 Tahun 1946 tentang Peraturan Hukum Pidana (KUHP). Jakarta, 1946.

Sekretariat Negara RI. Undang-Undang No. 23 Tahun 2002 tentang Perlindungan Anak, sebagaimana diubah dengan Undang-Undang No. 35 Tahun 2014 tentang Perubahan atas Undang-Undang No. 23 Tahun 2002 tentang Perlindungan Anak. Jakarta, 2002.

Sekretariat Negara RI. Undang-Undang No. 19 Tahun 2016 tentang Perubahan atas Undang-Undang No. 11 Tahun 2008 tentang Informasi dan Transaksi Elektronik. Jakarta, 2016.

\section{c. Website}

https://id.wikipedia.org./wiki/Intimidasi duni maya.

http://google.co.id/Naskah Akademik Rancangan Undang-Undang tentang informasi dan transaksi elektronik . 